\title{
A PRELIMINARY TEST OF NEUTRALITY
}

War creates no more perplexing international problems than those involving the relations between belligerents and neutrals. In times of peace the mutual relations of sovereign states are built upon the basis of complete reciprocity. The course of conduct which one nation has the right to expect and demand that other nations shall observe toward itself, is identical with that which it is its own duty to observe toward all other nations.

Upon the outbreak of war reciprocity necessarily fails as the standard by which the relations between neutrals and belligerents can be measured. Manifestly the duties which a neutral owes to a belligerent and the duties owed by the belligerent to the neutral are of a very different character. From this dissimilarity arises most of the difficulty attending a satisfactory adjustment of disputes between countries of the two classes. Justice based upon uniformity is of easy theoretical attainment; justice based upon mutual concessions between divergent interests is more difficult of attainment. In spite, however, of the difficulties in the way of the establishment of a fair equilibrium there can be no satisfactory solution of any of the problems concerning the relations between belligerents and neutrals which is not predicated upon the recognition of the principle that each has rights upon the high seas and elsewhere which the other is bound to respect.

It was long before belligerents could be induced to admit that neutrals possessed any rights which it was their duty to recognize. In early times the right of a belligerent to prey upon commerce which in any way benefited its opponents was virtually unrestricted, even although it extended to the seizure of the ships and cargoes of neutrals.

"The truth is that the Law of Neutrality is a comparatively modern growth, in so far as it deals with the mutual rights and duties of belligerent and neutral states. It has arisen during the last century from a recognition, dim at first but growing clearer and clearer as time went on, of the two principles of absolute impartiality on the part of neutrals and absolute respect for neutral sovereignty on the part of belligerents. But in so far as it deals with the right of belligerent states to put restraint on the commerce of neutral individuals, it is at least as old as the maritime codes of the Middle Ages, and in some of its 
provisions traces can be found of the sea laws of the Greeks and the Romans. Opposing self-interests are the operative forces which have determined the character of this part of the Law of Neutrality. At first the powers at war were able to impose hard conditions upon peaceful merchants. It was a favor for them to be allowed to trade at all, and they were not permitted to do anything that would impede the operations of the belligerents. Then, as commerce became stronger, concession after concession was won for neutral traders; and neutral states made common cause to protect their subjects from molestations they deemed unwarrantable. "The nineteenth century has seen the removal of many of the remaining shackles, and it can hardly be doubted that others will soon be struck off."1

The present attitude of belligerents toward neutrals, while a great improvement over the earlier attitude, still leaves much to be desired. On the other hand, neutrals are at times inclined to deny the just rights of belligerents. While an enlightened system of International Law should undoubtedly favor neutrals to the greatest possible extent, it must also recognize the due rights of belligerents; and the right of a neutral to demand proper treatment from a belligerent must always to a great degree be dependent upon the neutral's observance of its own duties. A neutral is only entitled to the rights of neutrals when it recognizes and performs the obligations of neutrals.

Furthermore, it is only by the strict observance of the rules governing the duties of neutrals to belligerents, that a neutral avoids the risk of being on the wrong side of a claim for damages; for the liability of a belligerent to account in damages for injuries inflicted upon a netttral by its violation of a belligerent's duties toward neutrals is no clearer than is the liability for damages of a neutral to a belligerent where the former has been guilty of a violation of its duties toward the latter.

It is therefore evident that a neutral which desires to be in a position to successfully assert all its rights as against belligerents must study not only the extent of these rights, but also the nature and extent of its duties to the belligerents.

The first and greatest of these duties is that of being neutral; and by neutrality can only be meant absolute neutrality. There is, and can be, no other form of neutrality. International Law knows nothing of the "qualified neutrality" sometimes referred

\footnotetext{
${ }^{1}$ Lawrence's Principles of International Law, p. 476.
} 
to by International Law writers of an earlier day, or of the "benevolent neutrality" which has first come into prominence during the present war. Any departure from a policy of strict non-discrimination between belligerents destroys the true neutrality of a nation.

Justice requires that the conduct not only of belligerents toward neutrals, but also that of neutrals towards belligerents, shall be determined by fixed legal principles. It is in the stormiest waters that there is the greatest need of accurate steering; and it is during times of warfare, when the rules of International Law are most apt to be disregarded, that there is the greatest need of strict adherence to these principles. The question next naturally arises as to what these principles of International Law are which should guide a neutral in framing its conduct toward belligerents. To attempt even an enumeration of all the rules necessary for the determination of each problem of this character which can arise would be an impossibility in a short article of this character.

There is, however, one preliminary rule which can be laid down which will furnish an accurate preliminary test of neutrality, and which in most cases will indicate the road which it is necessary to follow in order to arrive at the solution of any concrete question which may be presented to a neutral relative to its conduct toward a belligerent.

This test is to be found in the strict application of the principle that it is the duty of every neutral to govern all its actions which in any manner affect the interests of any of the belligerents, by the rules of International Law, as they existed at the time of the breaking out of the war. No neutral country has the right to attempt to modify the rules of International Law during the continuance of hostilities, nor to acquiesce in any attempt of the belligerents on one side to so change them. A neutral, during the continuance of hostilities, cannot act as an international law maker nor can a neutral while retaining an attitude of strict neutrality properly assume to pass upon the merits of the controversy being settled by the test of arms, nor give as an excuse for refusing to follow the existing rules of law, that in its opinion its adherence to these rules would work for the benefit of one or other of the belligerents. The adoption of the theory that any principle of International Law which works to the advantage of either belligerent must be suspended would mean the suspension of all International Law during the 
continuance of hostilities. What every belligerent is entitled to, and all that any belligerent has any right to ask, is that the war shall be fought out under the rules which existed at the time of the outbreak of hostilities.

An exception to this rule may perhaps seem to be found in an episode which occurred in that group of wars of which the American Revolution formed a part, when the principal neutral countries of Europe, by entering into the covenant known as the "Armed Neutrality" (and which embodied a demand for the recognition of the principles of maritime law which the Empress Catherine II of Russia in a proclamation issued March 8, I780, had announced that she was henceforth resolved to defend by force if necessary), succeeded in having certain entirely new principles incorporated into the body of International Law.

This exception, however, is much more apparent than real. As a matter of fact the so-called "armed" neutrality, like every other kind of neutrality which requires an adjective to define it, was in reality no neutrality. at all. It was a threat of hostility which succeeded because the country against which it was principally directed feared to take on any new antagonists. As a prominent historian has expressed it: "This covenant, known as the Armed Neutrality, was practically a threat aimed at England, and through her unwillingness to alienate Russia it proved a very effective threat."

The truth of the statement that the duty of a neutral is to closely observe the existing principles of International Law (including rules not of universal acceptance which have become binding upon the particular neutral, through its previous actions) is more readily seen if the proposition is put in its negative form and the question is asked: under what conditions a neutral country will be liable for the losses occasioned to a belligerent country (or its citizens or subjects) by the acts of the neutral. The answer is obviously that a neutral country can never be so liable except in cases where its action upon which the claim for damages is based, has constituted a violation of some existing principle of International Law. For losses resulting from any of their acts-either of commission or omission-which constituted such a violation, neutrals may and have been held liable to belligerents for the damages resulting therefrom.

Much light is thrown upon the basis upon which the liability of a neutral to a belligerent.may be predicated by a study of the negotiations between the United States and Great Britain leading 
up to the arbitration of the "Alabama" claims. The history of these negotiations reveals what is perhaps the most anomalous situation ever found in any important international arbitration. The principles involved were considered by both countries as being of far greater importance than the indemnity finally awarded, and for this reason great difficulty was experienced in so framing the questions to be presented to the arbitrators for . their consideration as not to put any stigma upon the conduct of either country. With regard to the legal questions involved the two countries disagreed upon every vital point except upon this preliminary principle, that the liability of Great Britain must be based-if it existed at all-upon the law as it existed at the time of the outbreak of the war.

The British commissioners who negotiated the Treaty of Washington, by the provisions of which the "Alabama" claims were submitted to arbitration, soon indicated that they were much less opposed to the payment by Great Britain of an indemnity to the United States, as compensation for the losses occasioned by the seizure and destruction of American ships by the "Alabama," than they were to an admission that there had been a violation of the principles of International Law on the part of Great Britain.

The United States commissioners proposed the adoption of certain rules which the arbitrators should be obliged to take as the principles of International Law governing the case. To this proposal it was replied by

"the British Commissioners that they were instructed to declare that they could not assent to the proposed rules as a statement of principles of international law, but that Her Majesty's Government, in order to evince its desire of strengthening the friendly relations between the two countries, and of making satisfactory provision for the future, agreed that in deciding the questions between the two countries arising out of those claims the arbitrator should assume that Her Majesty's Government had undertaken to act upon the principles set forth in the rules in question.".

The matter was thus settled under a compromise by which the British Government agreed that it should be "assumed" by the arbitrators that certain rules of law were binding* upon Great

'Moore's International Arbitrations, Vol. I, p. 543. 
Britain while that country expressly refused to "assent" or acknowledge that these rules had been actually binding upon her.

Article VI of the Treaty of Washington of I87r, which set forth the rules to be followed by the arbitrators, and explained the theory of the British Government as to their adoption, was in part as follows:

"In deciding the matters submitted to the Arbitrators they shall be governed by the following three rules, which are agreed upon by the High Contracting Parties as rules to be taken as applicable to the case, and by such principles of International Law not inconsistent therewith as the Arbitrators shall determine to have been applicable to the case: Rules- . . Her Britannic Majesty has commanded her High Commissioners and Plenipotentiaries to declare that Her Majesty's Government cannot assent to the foregoing rules as a statement of the principles of International Law which were in force at the time when the claims mentioned in Article $I$ arose, but that Her Majesty's Government in order to evince its desire of strengthening the friendly relations between the two countries and of making satisfactory provision for the future, agrees that in deciding the questions between the two countries arising out of those claims, the Arbitrators should assume that Her Majesty's Government had undertaken to act upon the principles set forth in these rules.

And the High Contracting Parties agree to observe these rules as between themselves in future, and to bring them to the knowledge of other maritime Powers, and to invite them to accede to them."

There was, therefore, never any agreement between the United States and Great Britain as to the theory under which the "Alabama" award was made, even after the arbitrators had rendered their decision and the award had been paid.

The position of the United States was always that the award was made for damages resulting from the failure of Great Britain to observe the duties imposed upon her as a neutral, if not by the general principles of International Law, at least by her own municipal regulations. The British Government on the other hand never at any time admitted that the rules under which the award was made were binding upon Great Britain at the time of the Civil War, and held that she merely agreed that certain new principles of International Law should have a retroactive effect. ${ }^{3}$

\footnotetext{
${ }^{3}$ The result of the award was accepted with general acquiescence in England on account of the general prevailing feeling in that country that
} 
Both countries, however, proceeded on the theory that a basis must be found to sustain the "Alabama" award either in principles of International Law which actually existed during the Civil War period, or in principles which it was agreed between the two countries the arbitrators might arbitrarily assume to have existed at that time.

No legal principle is broad enough to cover every case, and the rule that a neutral must observe the law as it existed at the outbreak of the war necessarily fails when confronted with some new problem of neutrality concerning which no binding rule of International Law has ever been adopted. In this connection it may be said that cases involving questions of International Law relative to the conduct of neutrals toward belligerents, fall into three classes:

First. Cases where the question as to the proper conduct of the neutral in some specific matter is covered by some sule of International Law fully established and universally recognized at the time of the outbreak of the war. In all such cases there can be no legitimate ground for doubt as to the proper action of the neutral; it is manifestly and absolutely its duty to strictly follow the recognized rule of International Law regardless of the effect of such action upon the fortunes of any of the belligerents.

Second. Equally plain is the duty of the neutral to follow the precedents which it has itself established in cases where questions are involved upon which there can not be said to be any generally accepted rule of International Law, but upon which the neutral nation has definitely committed itself by the conduct or decisions of its Executive or Judicial Department acting within the proper scope of its authority. This proposition is of especial importance in the United States on account of the many occasions upon which our Supreme Court, in its decisions, has asserted principles of International Law not accepted by the majority of other nations. In times of war between other countries this country, to be either consistent or just, must adhere to such of these decisions as affect the duties of neutrals toward belligerents, except in cases where the position taken by the

Great Britain had secured the adoption of a new principle of International Law liable to be of great benefit to her in the future, by permitting it to be made retroactive adversely to British interests in a single controversy. This might serve as an illustration of the old saying that during one war England is always fighting the next. 
Supreme Court was subsequently abandoned, prior to the opening of the war, by international agreement or otherwise.

Third. During the course of a long war questions will necessarily be presented to a neutral which are not to be answered by any of the generally accepted principles of International Law and upon which the neutral country has never committed itself prior to the outbreak of hostilities. In such cases, and in such cases only, there seems to be no sure test which can be used as the standard by which to measure the quality of the neutrality exercised.

WASHington, D. C.

Albert H. Putney. 